J. Product. \& Dev., 20(2): $211-226(2015)$

\title{
BREEDING STUDIES ON SOME AGRONOMIC AND QUALITY TRAITS IN RICE(Oryza sativa $\mathbf{L}$.)
}

\author{
Khaled F. M. Salem*, Y. M. Yaseen*, A. B. El-Abd** and A. Ayoub* \\ *Plant Biotechnology Department, Genetic Engineering and Biotechnology \\ Research Institute, Sadat City University, Sadat City, Egypt. \\ **Rice Research Section, Field Crops Research Institute, ARC, Giza, Egypt.
}

\section{ABSTRACT}

This study was aimed to study the heterosis, degree of dominance and minimum number of effective factors for yield components (Panicle length, Panicle weight and Grain yield/plant) and some grain quality traits in rice (Hulling percentage, Milling percentage and Head rice percentage) under normal conditions. The materials for this study consisted of six rice genotypes namely; Sakha101, Sakha102, Egyptian Yasmin, GZ1368s-5-4, IET1444 and IR78875-176-B2-B, These genotypes have a wide range of variation due to their different genetic background. The six rice parents were crossed to produce $F_{1}$ hybrid seeds of three crosses, namely, Sakha101 x GZ1368s-5-4(I), Sakha102 x IET1444(II) and Egyptian Yasmin $x$ IR78875-176-B2B(III). The six populations, $P_{1}$, $P_{2}, F_{1}, F_{2}, B C_{1}$ and $B C_{2}$ for each cross were utilized to determine the genetic parameters of the studied characters.

The results revealed that heterosis better parent values were highly significant in positive direction for all traits in all crosses in agronomy characters except for the cross III in panicle length character were negative direction. The mid parent values were highly significant in positive direction for all traits in all crosses in agronomy characters except for the cross I for panicle weight and cross III for panicle length character. Degree of dominance values were less than unity in the positive direction for the crosses I, II and III, for all agronomic traits except for cross II in traits panicle weight and grain yield plant and the cross III in Grain yield plan trait were negative direction, indicating the importance of partial dominance in the inheritance of this trait in these crosses, Moreover, the Castle-Wright formula revealed that the estimated values of minimum number of gene in Panicle length trait in the crosses I and II is simple trait governed by one or two pairs of genes while the cross III governed by large number of genes (-12.63). Panicle weight trait was controlled by less than two pairs of genes suggested that trait is qualitative character in the crosses I and III while the crosses II governed by large number of pair of genes more than 9 pair of genes. Meanwhile, 
the Grain yield plant trait governed by large number of genes in the three crosses suggested that trait is quantitative character.

On the other hand, the heterosis of quality traits revealed the hulling trait in mid parents and better parent were no significant except the cross II in mid parent while milling and head rice traits were highly significant in negative direction except the cross III in better parent to two traits. Obviously. degree of dominance values were less than unity in the negative direction for all crosses of hulling and milling traits for each crosses except the cross III were positive direction to two traits while the head rice trait was less than unity in all crosses in the positive direction except the cross I was negative.

These results indicating the importance of partial dominance in the inheritance of this trait in these crosses. The Castle-Wright formula revealed that the estimated values of minimum number of gene in hulling\% trait in the crosses I and III is simple trait governed by one or two pairs of genes while cross II governed by large number of genes (7.180),milling\% trait was controlled by (2.160, 4.100 and0.890) pairs of genes in the three studied crosses respectively. The head rice\% was governed by (2.470, -21.26 and 2.30) suggested that trait governed by large number of genes in crosses II.

Key words: Rice, breeding, heterosis, Yield components and Grain quality traits.

\section{INTRODUCTION}

Rice has always been one of the most important food crops in the world. It is estimated that 40 per cent of the world's population take rice as their major source of food. The advent of higher yielding semi dwarf varieties has been instrumental in achieving consistent progress in rice production in the past three decades and attaining self-sufficiency.

Rice is a highly self-fertilized plant, which means that pollen from the same flower or from another flower on the same plant will pollinate itself. Pollen is shed from the stamens and lands on the pistil of either the same flower or another flower of the same plant over $95 \%$ of the time.

In Egypt, rice is considered as one of the most important field crops, since it contributes about $20 \%$ of the total cereal consumption. Annually, more than one and half million feddans is cultivated with rice (one feddan $=4200 \mathrm{~m} 2$ ) producing about 6.5 million tons of rice, with an average of 4.6 ton/fed. (10.9 ton/ha) (RRTC, 2013).

Success in crop improvement generally depends on the magnitude of genetic variability and the extent to which the desirable characters are heritable. 
Development of high-yielding varieties requires a thorough knowledge of the existing genetic variation for yield and its components and grain quality traits. The observed variability is a combined estimate of genetic and environmental causes, of which only the former one is heritable. However, estimates of heritability alone do not provide an idea about the expected gain in the next generation, but have to be considered in conjunction with estimates of genetic advance. Grain yield character in rice is quantitative trait in nature and is polygenically controlled. Selection on the basis of grain yield character alone is usually not very effective and efficient. However, selection based on its component characters could be more efficient and reliable. Quality is defined as a major factor which decides market values of agricultural products and foods in each phase from production through consumption. Rice grain quality has always been an important consideration in rice variety selection and development, it is second only to yield as a major breeding and thus relates to a number of factors, while the cooking and eating quality is a part of the factors in assessing the grain quality of rice.

In the future, grain quality will be even more important once, the very poor-many of whom depend largely on rice for their staple food become better off and begin to demand higher quality rice.

\section{MATERIALS AND METHODS}

The present study was laid out at the Experimental Farm of Rice Research and Training Center (RRTC), Sakha, Kafer EL-Shiekh, Egypt, during three successive rice growing seasons, 2010, 2011 and 2012 to study the heterosis, degree of dominance and minimum number of effective factor of som grain yield, its components and some grain quality traits in rice under normal conditions. The materials for this study consisted of six rice genotypes namely; Sakha101, Sakha102, Egyptian Yasmin, GZ1368s-5-4, IET1444 and IR78875-176-2B, it was chosen as parents based on previous studies. These genotypes have a wide range of variation due to their different genetic background.

The six rice parents were crossed to produce $F_{1}$ hybrid seeds of three crosses. These three crosses were: Sakha101 x GZ1368s-5-4, Sakha102 x IET1444 and Egyptian Yasmin $x$ IR78875-176-2B. The six populations, $\mathrm{P}_{1}, \mathrm{P}_{2}$, $\mathrm{F}_{1}, \mathrm{~F}_{2}, \mathrm{BC}_{1}$ and $\mathrm{BC}_{2}$ for each cross were utilized to determine the genetic parameter of the studied characters.

\section{1-Experimental field procedures:}

In 2010 season, the parental genotypes were grown at RRTC farm in three planting dates with ten days interval in order to overcome the differences in flowering time between parents. Thirty days old seedling of each parent was 
individually transplanted in the field in 10 rows. Each row was $5 \mathrm{~m}$ long and included 25 hills. At flowering time, hybridization between parents was carried out following the technique proposed by Jodon (1938) and modified by Botany(1961) and the aforementioned three crosses were produced.

In 2011 season, parents and $F_{1}$ hybrid seeds of the three crosses together with their parental lines were planted under normal conditions.

At heading, parents were crossed again to produce the $F_{1}$ hybrid seeds of three crosses following the same technique. Moreover, some of $F_{1}$ plants were left to be self pollinated in order to produce $\mathrm{F}_{2}$ seeds, while some other plants were crossed with their own parents as a male to produce $\mathrm{BC}_{1}$ and $\mathrm{BC}_{2}$ seeds. At harvest, seeds of different generations were individually harvested to be grown in the next season.

Subsequently, in 2012, summer season, seeds of the $\mathrm{P}_{1}, \mathrm{P}_{2}, \mathrm{~F}_{1}, \mathrm{BC}_{1}, \mathrm{BC}_{2}$ and $\mathrm{F}_{2}$ of each cross were sown in normal conditions to estimate the genetic parameters of the three rice agronomic characters (Panicle length, Panicle weight and Grain yield/plant) and three rice quality characters (Hulling percentage, Milling percentage and Head rice percentage). Eighteen entries belongs to different generations (6 parents, 3F1's, 3F2's, 3BC1, 3BC2) were cultivated in a randomized complete block design experiment with four replication. Each replicate contained 10 rows of each $\mathrm{P}_{1}, \mathrm{P}_{2}, 5$ rows of each of $\mathrm{F}_{1}, \mathrm{BC}_{1}$ and $\mathrm{BC}_{2}$ and 15 rows of $\mathrm{F}_{2}$ generations.

\section{2-Studied characters}

\section{a-Agronomic and yield traits}

1-Panicle length $(\mathbf{c m})$ : The main panicle of each plant was measured from the base of panicle to its tip, excluding awns, at complete maturity stage.

2-Panicle weight (g): The weight in grams of main panicle was estimated at complete maturity stage.

3-Grain yield/plant (g): It was recorded as the weight in grams of the individual plant grain yield and adjusted to $14 \%$ moisture content.

\section{b-Grain quality traits:}

1-Hulling percentage: duplicate ten grams of rough rice from each individual plant were used for hulling percentage determination. Hulling percentage was calculated according to Khush et al. (1979) as follows:

$$
\begin{gathered}
\text { Brown rice weight }(\mathrm{g}) \\
\text { Hulling } \%=\text {------------ x } 100 \\
\text { Total rough rice weight }(\mathrm{g})
\end{gathered}
$$

2-Milling percentage: the objective of rice milling is the removal of bran and germ with the minimum breakage of the endosperm. Milling percentage was determined according to Ghosh et al. (1971) as follows: 


$$
\text { Milling \% }=\frac{\text { Total milled rice weight }(\mathrm{g})}{\text { Total rough rice weight }(\mathrm{g})}
$$

3-Head rice percentage: the whole grains (head rice grains)/panicle were separated according to the broken size (less than $14_{\text {th }}$ of grain length) with rice-sizing device and then weighted. Head rice percentage was determined as follows:

$$
\text { Head rice } \%=\frac{\text { Weight of head rice }(\mathrm{g})}{\text { Milled rice weight }(\mathrm{g})}
$$

In all growing seasons of the study, all cultural practices such as field preparation, sowing method, transplanting and fertilizers, weed control were applied as recommended.

\section{3-Statistical and genetic analysis:}

\section{I- Estimation of heterosis:}

Heterosis relative to mid parent or better parent average values were estimated according to Mather (1949) and Mather and Jinks (1971):

F1 - M.P.

Heterosis over the mid parent $(\%)=----------\mathrm{x} 100$

$$
\text { M.P. }
$$

F1 - B.P.

Heterosis over the better parent $(\%)=$------------ x 100

B.P.

Where: $\mathbf{F}_{\mathbf{1}}=$ Mean value of the first generation, $\mathbf{M . P}=$ Mean value of mid parent calculated by using average mean of the tow parents and B.P = Mean value of the better parent.

\section{II-Estimation of the nature of dominance and its directions:}

The relative of potency ratio $(\mathrm{P})$ was used to determined the degree of dominance and its directions according to the formula given by Mather and Jinks (1971) as follows:

$$
\text { Potency ratio }(\mathrm{P})=\frac{\mathrm{F}_{1}-\mathrm{M} . \mathrm{P}}{\mathrm{1} / 2\left(\mathrm{P}_{2}-\mathrm{P}_{1}\right)}
$$

Where: $\mathbf{F}_{1}=$ the mean of the first generation, $\mathbf{P}_{\mathbf{1}}=$ the mean of the low Parent,

$\mathbf{P}_{\mathbf{2}}=$ the mean of the high Parent and $\mathbf{. P} .=$ the value of mid parent.

- Absence of dominance, is indicated when dominance ratio is equal to zero,

- Partial dominance is considered when ratio is between 1.0, and -1.0,

- Complete dominance is assumed when the ratio equals either \pm 1.0 , and

- Over dominance is indicated when the ratio exceeds either \pm 1.0 . 


\section{III-Estimation of the minimum number of effective factors controlling characters:}

The number of gene pairs responsible for the parental difference for each character is determined by the following methods according to CastleWright-formula (1921)

$$
\mathrm{N}=\frac{\left(\mathrm{P}_{1}-\mathrm{P}_{2}\right)^{2}}{8\left(\mathrm{VF}_{2}-3 \sqrt{ }\left(\mathrm{VP}_{1} \cdot \mathrm{VP}_{2} \cdot \mathrm{VF}_{1}\right)\right.}
$$

Where: $\mathbf{N}=$ Minimum number of genes controlling trait, $\mathbf{P}_{\mathbf{1}}-\mathbf{P}_{\mathbf{2}}=$ Difference between the parental means, $\mathbf{V F}_{\mathbf{2}}=$ Variance of $\mathrm{F}_{2}$ generation and $\mathrm{VP}_{1}, \mathrm{VP}_{2}$ and $\mathrm{VF}_{1}=$ Variance of the first parent, Second parent and $F_{1}$ generation, responsively.

\section{The formula assumes the following :}

a) Equal effect of genes involved, b) Additive gene action, c) Absence of dominance, d) Maximum range exists between parents, e) One parent contributes only genes with plus effects and the other parent contributes only genes with minus effects.

\section{RESULTS AND DISCUSSION}

The percentage of heterosis as deviation from mid parent (MP) and better parent (BP), degree of dominance and the minimum number of effective factors controlling panicles and yield characters (Panicle length, Panicle weight and Grain yield/plant) are presented in Table (1) and quality characters (Hulling percentage, Milling percentage and Head rice percentage) are presented in Table 2.

\section{a- Agronomic and yield traits:}

The percentage of heterosis as deviation from mid parent (MP) and better parent (BP), degree of dominance and the minimum number of effective factors controlling agronomic characters are presented in Table 1.

\section{1-Panicle length}

Table (1) reveals that highly significant and positive estimates of heterosis were recorded for panicle length (13.96 and 5.58) in crosses I and II, respectively, when it was measured as a deviation from better parent as well as in cross II, (5.58), when it was measured as a deviation from mid-parent. On the contrary, highly significant and negative estimates of heterosis were obtained in cross III, when it was measured as a deviation from mid an d better parent, (-10.18 and 10.89), respectively. The results suggested that heterosis played important role in the inheritance of panicle length in cross II. These results were in harmony with 
Table 1: Estimates of heterosis as a deviation from mid-parent (MP) and better parent (BP), degree of dominance and minimum number of genes for agronomic characters, panicle length $(\mathrm{cm})$, panicle weight $(\mathrm{gm})$ and Grain yield $\backslash$ plant $(\mathrm{gm})$ in the three studies crosses.

\begin{tabular}{|l|c|c|c|c|c|}
\hline \multirow{2}{*}{ Character } & \multirow{2}{*}{ Cross } & \multicolumn{2}{|c|}{ Heterosis } & \multirow{2}{*}{$\begin{array}{c}\text { Degree of } \\
\text { dominance }\end{array}$} & $\begin{array}{c}\text { No. of } \\
\text { minimum } \\
\text { genes }\end{array}$ \\
\cline { 3 - 4 } & & BP & MP & & \\
\hline \multirow{2}{*}{ Panicle } & I & $8.44^{* *}$ & 2.26 & 0.01 & 1.40 \\
length (cm) & II & $13.96^{* *}$ & $5.58^{* *}$ & 0.03 & 1.76 \\
& III & $-10.18^{* *}$ & $-10.89^{* *}$ & 0.06 & -12.63 \\
\hline \multirow{2}{*}{ Panicle } & I & $1.15^{* *}$ & $-2.98^{* *}$ & 0.02 & 0.27 \\
weight (g) & II & $20.22^{* *}$ & $17.79^{* *}$ & -0.53 & -9.81 \\
\hline \multirow{2}{*}{ Grain yield/ } & III & $9.93^{* *}$ & $2.34^{* *}$ & 0.03 & -1.43 \\
plant (gm) & II & $34.54 * *$ & $18.93^{* *}$ & 0.017 & -2.63 \\
\hline
\end{tabular}

Where: Crosses I, II and III were Sakha 101 x GZ1368s-5-4, Sakha 102 x IET1444 and Egyptian Yasmin x IR78875-176-B2-B, respectively.

$*$ and **: Significant at $0.05,0.01$ probability levels, respectively.

finding reported by Kole and Hasib (2005), Rosamma and Vijayakumar (2005), Chitra et al. (2006) and Senguttuvel et al. (2006).

Degree of dominance values were less than unity $(0.01,0.03$ and 0.06$)$ for crosses I, II and III, respectively, indicating the importance of partial dominance in the inheritance of this trait in these crosses. The tallest panicle was partially dominant over the shortest panicle in all crosses. The same results were obtained by Chitra et al. (2006), Senguttuvel et al. (2006), El-Naem (2010). Rahimi et al. (2010). Varpe et al. (2011). Abd El-Lattef et al. (2012). Nevame et al. (2012), Parimala and Cheralu (2012) and Anil Kumar and Mani (2013).

Results in Table (1) show that the minimum number of genes controlled this trait were $(1.4,1.76$ and -12.63) in all studied crosses, respectively. These findings indicating that almost two to thirteen pairs of genes were governed such traits. Similar results were reported by El-Abd (1999), Abd El-Aty et al. (2002), Abd El-Lattef et al. (2008) and Abd El-Lattef et al. (2012).

\section{2- Panicle weight}

Results in Table (1) show that highly significant and positive estimates of heterosis were detected in all crosses, when it was measured as a deviation from mid and better parent, except that of recorded for mid parent in cross I, which found to be in negative direction $(-2.98)$. The highest positive estimated values were recorded in cross II, (20.22 and 17.79), when it was measured as a 
deviation from better and mid parent, respectively. These findings were supported by those reported by Agrawal (2003), Kole and Hasib (2005) and Sonika et al. (2009).

Results in Table (1) Show that the degree of dominance was lower than unity $(0.02,-0.53$ and 0.03$)$ in the crosses I, II and III, respectively, suggesting the importance of partial dominance in the inheritance of this trait in these crosses. The heaviest panicle was partially dominant over the lightest panicle in the crosses I and III. On the other hand, the lightest panicle was partially dominant over heaviest panicle in the cross II. Similar results were reported by Lakshmana et al. (2007) and Sonika et al. (2009).

Meanwhile, the minimum number of effective factors controlling panicle weight trait were $(0.27,-9.81$ and -1.43) in the three studied crosses, Sakha 101 x GZ1368s-5-4, Sakha 102 x IET1444 and Egyptian Yasmin x IR78875-176$\mathrm{B} 2-\mathrm{B}$, respectively, indicated that this trait was controlled by one to two genes in the crosses I and III, respectively, while it was governed by large numbers of pairs of genes in cross II. Same results were reported by Abd El-Aty et al. (2002), Agrawal (2003) and Kole and Hasib (2005).

\section{3- Grain yield/plant}

It is evident in Table (1) that heterosis percentage as a deviation from better parent and mid parent was highly significant and positive. The highest estimated values were reported in cross II, followed by the cross III and cross I, when it was measured as a deviation from better parent, respectively. However, the highest estimates values of mid parent heterosis were recorded for grain yield /plant in the same crosses with the same ranking, their estimated values were $(68.19,35.6$ and 18.93), respectively. These results were similarly with these reported by ElRewainy et al. (2011), Chougule et al. (2012), Hussain and Sanghera (2012), Nevame et al. (2012), Reddy et al. (2012), and El-Naem (2014).

Data of degree of dominance values shown in Table (1) indicate that there were fewer than unity in all the studied crosses, suggesting that partial dominance was involved the controlling of such character in all the studied crosses. Their estimated values were $(0.017,-0.19$ and -0.05$)$ in crosses, I, II and III, respectively, indicating that high yielding ability was partially dominant over low yielding ability in the first cross, while, low yielding ability was partially dominant over high yielding ability in the other two crosses. These results were agree with Hammoud (2005), Abd El- Lattef et al. (2008)and Abd El- Lattef et al. (2012).

The Castle-Wright formula revealed that the estimated values of minimum number of gene were $(-2.63,-18.4$ and -4.26$)$ in the three studied crosses, Sakha 101 x GZ1368s-5-4, Sakha 102 x IET1444 and Egyptian Yasmin $x$ IR78875-176-B2-B, respectively. suggesting the cross I, was 
controlled by almost three pairs of gene, cross II was controlled by large numbers of pairs of genes more than eighteen pairs of gene and the cross III was controlled by almost five pairs of gene, Similar results were recorded previously by El-Abd (1999), Abd El-Aty et al. (2002) and Parimala and Cheralu (2012).

\section{b- Grain quality characters 1-Hulling percentage}

It clear from Table (2) that hulling percentage exhibited undesirable highly significant and negative estimates $(-2.52)$ of heterosis as a deviation from mid-parent in the cross II, while, heterosis estimates were not significant in the other two crosses, I and III, when it was measured as a deviation from mid and better parent. Moreover, no significant and negative estimates of heterosis were found as a deviation from better parent in the cross II. The present conclusion was confirmed with the results obtained by Raju et al. (2003), El-Abd and Abd-Allah (2004) and El-Mouhamady et al. (2013).

In the present investigation, as shown in Table (2), the degree of dominance $(-0.006,-0.02)$ in the crosses I and II, respectively were lower than unity in negative direction, suggesting that low hulling \% was controlled by partial dominance or incomplete dominance, in addition, low hulling $\%$ was dominant over high hulling $\%$ in these two crosses. On the other hand,, the degree of dominance (0.103) was also lower than unity in the cross III, but it was in positive direction, indicating partial or incomplete dominance was involved in controlling hulling percentage, and high hulling \% was dominant over low hulling \% in this cross. Thus it could be concluded that the estimates of dominance genetic variances were differ according to the cross itself. These results were agreement with those obtained by Khedikar et al. (2003), El-Abd et al. (2009) and El-Refaee and Abdulmajid (2011).

Castle -Wright formula gave an estimates of $(-0.057)$ pairs of genes in the first cross, (7.180) pairs of genes in the second cross and (-1.470) pairs of genes in the last cross, Table (2). These estimations suggested that the minimum number of genes were differed depended on the cross itself, the mean difference for hulling percentage in the three studied crosses may have been governed by one, eight and two pairs of genes in the cross I, II and III, respectively, indicating that hulling \% was found to be simple trait, it was controlled by few number of genes. The present conclusion were confirmed the results obtained by El-Hissewy et al. (1988), Hsieh and Wang (1988) and ElAbd (1999).

\section{2-Milling percentage}

Obviously, Table (2) shows that undesirable highly significant in negative direction heterosis estimates were found in the two crosses namely, Sakha 101 
Table (2): Estimates of heterosis as a deviation from mid-parent (MP) and better parent (BP), degree of dominance and minimum number of genes for quality characters, Hulling\% Milling\% and Head rice\% in the three studies crosses.

\begin{tabular}{|l|c|c|c|c|c|}
\hline \multirow{2}{*}{ Character } & \multirow{2}{*}{ Cross } & \multicolumn{2}{|c|}{ Heterosis } & \multirow{2}{*}{$\begin{array}{c}\text { Degree of } \\
\text { dominance }\end{array}$} & $\begin{array}{c}\text { Minimum } \\
\text { genes }\end{array}$ \\
\cline { 3 - 4 } Hulling\% & I & -0.030 & -0.490 & -0.006 & -0.057 \\
& II & -0.660 & $-2.52 * *$ & -0.020 & 7.180 \\
& III & 1.610 & 0.510 & 0.103 & -1.470 \\
\hline \multirow{2}{*}{ Milling\% } & I & $-4.85 * *$ & $-6.93 * *$ & -0.060 & 2.160 \\
& II & $-8.82 * *$ & $-10.74 * *$ & -0.009 & 4.100 \\
& III & -1.620 & $-3.39 * *$ & 0.011 & 0.890 \\
\hline \multirow{2}{*}{ Head } & I & $-6.43 * *$ & $-8.85 * *$ & -0.055 & 2.470 \\
rice\% & II & $-22.07 * *$ & $-23.9 * *$ & 0.011 & -21.26 \\
& III & -4.450 & $-6.27 * *$ & 0.051 & 2.300 \\
\hline
\end{tabular}

Where: Crosses I, II and III were Sakha 101 x GZ1368s-5-4, Sakha 102 x IET1444 and Egyptian Yasmin x IR78875-176-B2-B, respectively.

$*$ and $* *$ : Significant at $0.05,0.01$ probability levels, respectively.

x GZ1368s-5-4 and Sakha 102 x IET1444, when it was measured as a deviation from better parent and mid parent, their estimated values were (-4.85 and -8.82$)$ and (-6.93 and -10.74$)$, respectively. Either insignificant negative or highly significant negative estimates of heterosis (-1.62 and -3.39) were measured as a deviation from better parent and mid parent in Egyptian Yasmin x IR78875176-B2-B rice cross, this in turn suggested that heterotic effect played an important role in the inheritance of milling $\%$ in undesirable negative direction. Significant and positive heterosis over mid parent values and significant or insignificant negative heterosis estimates were found and differed from cross to cross by El-Naem (2010).

It is clear from Table (2) that the values of degree of dominance were ($0.060,-0.009$ and 0.011 ) for all the studied crosses, I, II and III, respectively, it were lower than unity $(-1<\mathrm{P}>+1)$ suggested that partial dominance was involved in the control such character in all the studied crosses. High milling return was partially dominant over low milling return in cross, III. On the contrary, low milling return was partially dominant over high milling return in crosses, I and II. Similar findings were obtained previously by Sultan et al. (2010), Hassan et al. (2011) and El-Naem (2014).

Table (2) show that the Castle and Wright formula exhibited the minimum number of effective factors controlling milling \% in the three studied crosses. Their estimates were $(2.16,4.10$ and 0.89$)$ in the three studied crosses 
I, II and III, respectively, suggested some difference between the genes for such trait in parental used. Milling trait was governed by three, five and one pair of major genes in these studied crosses, respectively. These findings were agreed with those obtained by Hsieh and Wang (1988) and El-Abd (1999).

\section{3-Head rice percentage:}

It is evident in Table (2) that heterosis percentage as a deviation from midparent were highly significant and negative in the three studied crosses, their estimated values were $(-8.85,-23.9$ and -6.27$)$, respectively. On the other hand, highly significant and negative estimates of heterosis were recorded in the crosses, I and II, when it was measured from better parent, while, such estimates were no significant in negative direction in the cross, III. This in turn suggested that undesirable heterotic effect played an important role in the inheritance of head rice percentage, which is upon the cross itself. Similar results were obtained by El-Naem (2010), Sultan et al. (2010) and Hassan et al. (2011).

Furthermore, the degree of dominance were $(-0.055,-0.011$ and -0.051$)$ in the crosses, I, II and III respectively. As shown in Table (2) the potence ratio was lower than unity, suggested the importance of partial dominance in these three crosses, unbroken rice grains were partial dominant over broken rice grains in crosses, II and III. On the contrary, broken rice grains were partial dominant over unbroken rice grains in cross, I. The same results were obtained by El-Abd et al. (2008), Sultan et al. (2010) and Hassan et al. (2011).

The Castle-Wright formula gave an estimate of (2.47, -21.26 and 2.3) pairs of genes in the three studied crosses, respectively. this formula indicated that almost three pairs of genes were controlled head rice percentage in the crosses I and III, while, large number of pairs of genes (more than twenty) were played a remarkable role in the controlling of head rice percentage in cross II. These results were agreed with the results obtained by Hsieh and Wang (1988), El-Abd (1999), Kheduikar et al. (2003) and Raju et al. (2003).

\section{REFERENCES}

Abd El-Aty, M. S.; A. B. El-Abd and A. A. Abdallah. 2002. Genetic analysis of quantitative traits in rice. 1- Yield and its related characters. J. Agric. Sci. Mansoura Univ., 27(7): 4399-4408.

Abd El-Lattef, A. S. M.; A. B. El-Abd; A. A. Madyan and W. M. H. ElKhouby. 2008. Inheritance of earliness, grain yield and some grain quality traits in rice (Oryza sativa L.). Under water deficiency conditions. J. Agric. Res. Kafer El-Sheikh Univ. 34(4): 993-1019. 
Abd El-Lattef, A. S.; A. A. B. Abo-Khalifa and A. A. A. El-Gohary. 2012. Inheritance of some quantitative characters under drought conditions in rice (Oryza sativa L.). International Journal of Biology, Pharmacy and Allied Sciences (IJBPAS), June, 2012, 1(5): 620-635.

Agrawal, K. B. 2003. Heterosis in rice. Annals of Agricultural Research. 24(2):375-378.

Anil, Kumar and S. C. Mani. 2013. Nature and magnitude of heterosis and inbreeding depression for grain yield and yield attributing traits in basmati rice (Oryza sativa L.). Pantnagar Journal of Research.11(1):50-57.

Botany, W.T. 1961. Mass emasculation in rice. Inster. Rice Comm. Newsletter. 9: 9-13.

Castle,W.E.and S. Wright (1921).An improved method of estimating the number of genetic factors in cases of blending inheritance. Science 54: 223.

Chitra, S.; C. R. A. Kumar and L. Subha. 2006. Studying heterosis for grain yield and its components in F1 (hybrid) rice. Research on Crops. 7(2):437-439.

Chougule, G. R.; H. D. Mehta and S. A. Patil. 2012. Heterosis for qualitative and quantitative traits in rice (Oryza sativa L.). Crop Research (Hisar). 44(3):386-390.

El-Abd, A. B. A. 1999. A study on the inheritance of rice grain quality and its relation with yield and some yield related characters. Ph.D. Thesis, Fac. of Agric. Al-Azhar Univ. Egypt.

El-Abd, A. B. and A. A. Abd-Allah. 2004. Genetic behaviour of some grain quality characters in rice (Oryza sativa L.). Egyptian J. of Agric. Res. 82(1): 167-182.

El-Abd, A. B.; M. Sh. El-Keredy; M. S. Abd El-Aty and H. M. Hassan 2009 Detection of epistasis and estimation of additive and dominance components of genetic variation using triple test cross analysis in rice(Oryza sativa L.). 6th International Plant Breeding Conference, Ismailia, Egypt, May 3-5: 631-647.

El-Abd, A. B.; S. E. M. Sedeek; S. A. A. Hammoud and A. A. Abd Allah. 2008. Studies on genetic variability, heritability and genetic advance for grain yield and grain quality traits in some promising genotypes of rice (Oryza sativa L.). J. Agric. Res. Kafr El-Sheikh Univ., Egypt. 34(1): 71-97.

El-Hissewy, A. A.; A. E. Draz; I. R. Aidy and M. S. Balal. 1988. Genetic analysis of the physical properties of grain and gelatinization temperature in rice (Oryza sativa L.). J. Agric. Res., Tanta Univ., 14(2)(11):1226-1238.

El-Mouhamady, A. A.; A. A. Abdel-Sattar and E. H. El-Seidy. 2013. Assessment the degree of drought tolerance in rice through the environmental tests and molecular markers technique. Journal of Agriculture and Biological Sciences. 9(1): 40-57. 
El-Naem, S. A. 2010. Breeding studies on rice (Oryza sativa L.) under water stress conditions. M.Sc. Thesis, Fac. of Agricultural, Mansoura Univ., Egypt.

El-Naem, S. A. 2014. A study on gene interaction in the inheritance of grain yield, its components and some root and grain quality traits in rice under water stress condition. Ph D. Thesis, Fac. of Agric., Mansoura Univ., Egypt.

El-Refaee, Y. Z. and D. A. Abdulmajid. 2011. Heterosis analysis for physiomorphological traits and yield in relation to drought tolerance in rice (Oryza sativa L.). Egyptian Journal of plant breeding. 15(2): 175-192.

El-Rewainy, I. M. O.; H. M. Hassan and A. B. El-Abd. 2011. A study on heterosis and combining ability for grain yield and some its related traits in rice under water stress conditions. J. Agric. Res. Kafer El-Sheikh Univ. 37(4): 583-598.

Ghosh, A. K.; B. B. Nanda; S. Govindaswamy and B. B. Nayak 1971. Influence of nitrogen on the physicochemical characteristics of rice grain. Oryza, 8(1):87-98.

Hammoud, S. A. 2005. Genetic behaviour of some agronomic characters in two rice crosses. Egyptian Journal of Agriculture Res., 83 (SB): 305-322.

Hassan, H. M.; A. B. El-Abd and N. M. El-Baghdady. 2011. Combining ability for some root, physiological and grain quality traits in rice (Oryza sativa L.) under water deficit condition. J. Agric. Res. Kafr El-Sheikh Univ., Egypt. 37(2):239-256.

Hsieh, S. C. and L. H. Wang. 1988. Genetic studies on grain quality in rice. Special-Publication, Proceedings of a Symposium held at Taichung District Agricultural improvement Station, 13:117-136.

Hussain, W.; and G. S. Sanghera. 2012. Exploitation of heterosis in rice (Oryza sativa L.) using CMS system under temperate conditions. Electronic Journal of Plant Breeding. 3(1):695-700.

Jodon, N. E. 1938. Experiment on artificial hybridization of rice. J. Amer. Soci. Argon., 30:249-305.

Khush, G. S.; C. M. Paule and N. M. Dela Cruz. 1979. Rice grain quality evaluation and improvement at IRRI. Proc. The Workshop on "Chemical aspects of rice grain quality". IRRI, Los Banos, Philippines.

Khedikar, V. P.; A. A. Bharose; D. Sharma and Y. P. Khedikar. 2003. Studies on genetic parameter in scented rice genotypes. Journal of Soils and Crops. 13(2):338-342.

Kole, P. C. and K. M. Hasib. 2005. Mutant heterosis in aromatic rice. Tropical. Agriculture. 82(4):319-324.

Lakshmana, D.; B. G. S. Reddy and S. Ramesh. 2007. Heterosis studies in rice bean (Vigna umbellata (Thunb.) Ohwi and Ohashi). Legume Research. 30(3):209-211. 
Mather, K. 1949. Biometrical Genetic. Dover Publication, inc. London.

Mather, K. and J. I. Jinks. 1971. Biometrical Genetics. Cornell Univ. Press Ithaca, N.Y., 231pp.

Nevame, A. Y. M.; A. Efisue; Zhang SiSong; D. Samoura; Huang Feng; He Wen Chuang; Xie GuoSheng and Jin DeMing. 2012. Identification of interspecific grain yield heterosis between two cultivated rice species Oryza sativa L. and Oryza glaberrima Steud. Australian Journal of Crop Science. (11):1558-1564.

Parimala, K. and C. Cheralu. 2012. Combining ability studies in indica and japonica genotypes of rice. Crop Improvement. 39(1):127-129.

Rahimi, M.; B. Rabiei; H. Samizadeh and A. K. Ghasemi. 2010. Combining ability and heterosis in rice (Oryza sativa L.) cultivars. Journal of Agricultural Science and Technology. 12(2):223-231.

Raju, C. S.; M. V. B. Rao; G. L. K. Reddy; J. S. P. Rao and K. S. Reddy. 2003. Heterosis and combining ability for some quality traits in rice (Oryza sativa L.). Annals of Agricultural Research. 24(2):227-233.

Reddy, M. R.; C. S. Raju; D. Sravani; T. D. Reddy and G. N. Reddy. 2012. Heterosis for yield and kernal size in aromatic rice (Oryza sativa $\mathrm{L}$ ). Annals of Biological Research. 3(6):2662-2666.

Rosamma, C. A. and N. K. Vijayakumar. 2005. Heterosis and combining ability in rice (Oryza sativa L.) hybrids developed for Kerala state. Indian Journal of Genetics and Plant Breeding. 65(2):119-120.

RRTC. 2013. The Thirteen National Rice Research and Development Program Workshop. RRTC., ARC., Egypt. pp. 45.Sciences. 82(4):293-303.

Senguttuvel, P.; J. R. K. Bapu and K. S. Pandian. 2006. Heterosis breeding in rice for higher yields. Plant Archives. 6(1):261-263.

Sonika; J. P. Singh; M. P. Pandey and H. Singh. 2009. Studies on heterosis in rice hybrids using thermosensitive genic male sterile lines. Indian Journal of Genetics and Plant Breeding. 69(2):157-158.

Sultan, M. S.; M. A. Andel-Moneam; A. B. El-Abd and S. A. El-Naem. 2010. Genetic behavior and combining ability for some traits of root, physiological and grain quality traits in rice under water stress conditions. J. Plant Prod., Mansoura Univ., 1(12):1721-1734.

Varpe, P. G.; R. D. Vashi; P. P. Patil; S. R. Patil and V. A. Lodam. 2011. Heterosis for various qualitative traits in rice (Oryza sativa L.). Trends in Biosciences. 4(1):91-94. 


\section{دراسـات على تربيـة بعض الصفـات المحصولية وصفـات جودة

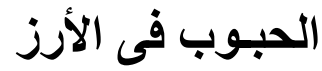

خالد فتحى سدالم - يس محمد يس - عبد المعطى بسيونى العبد -

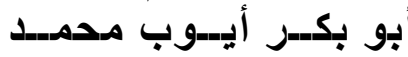

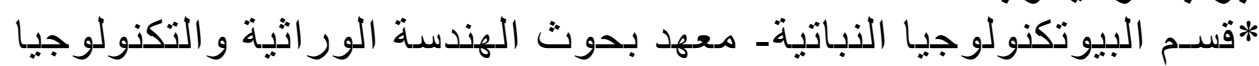

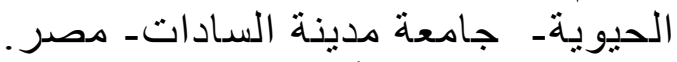

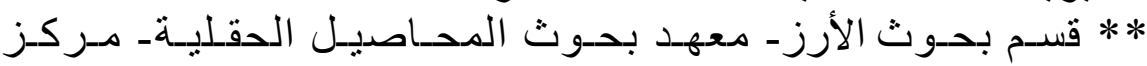

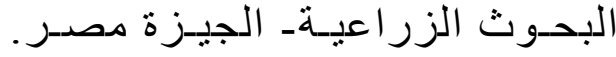

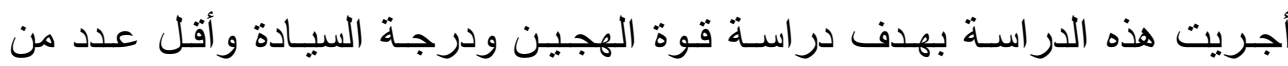

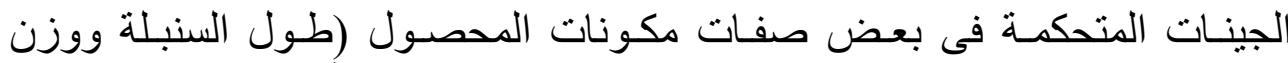

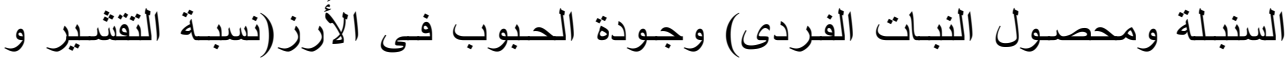

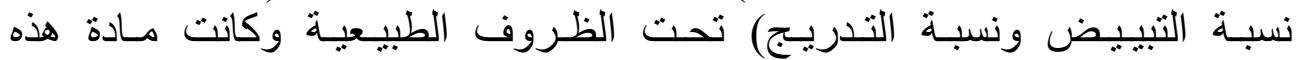

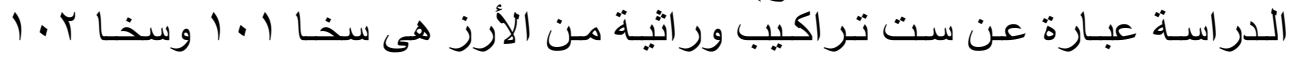
و البـاسمين المصـرى و GZ1368s-5-4 و و و

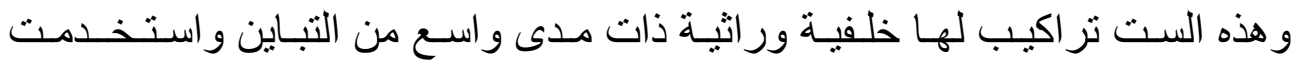

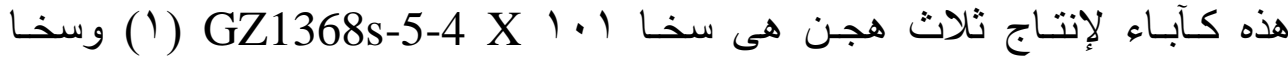

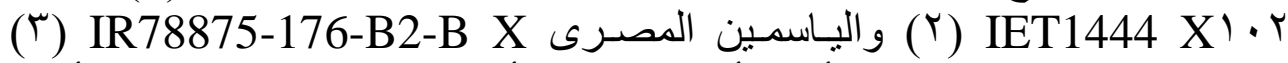

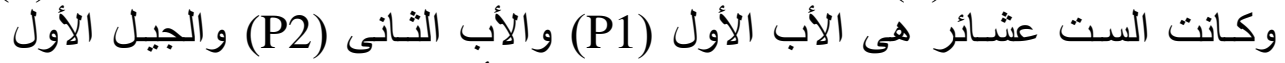

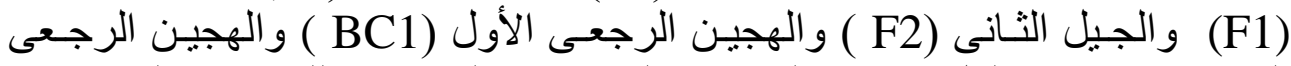

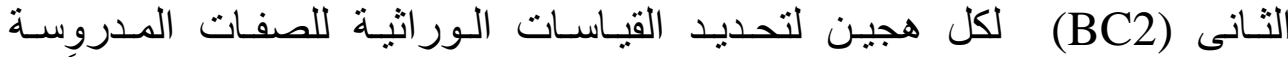

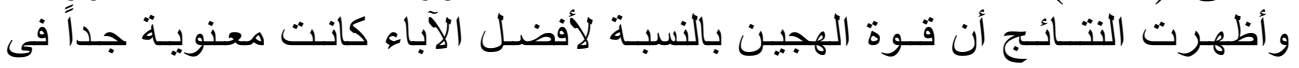

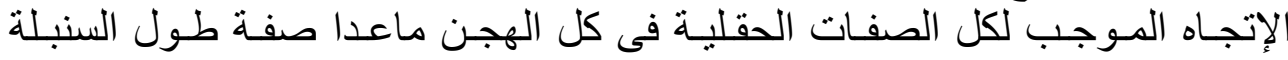

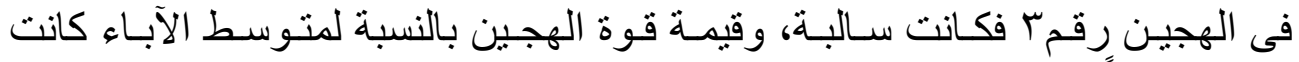

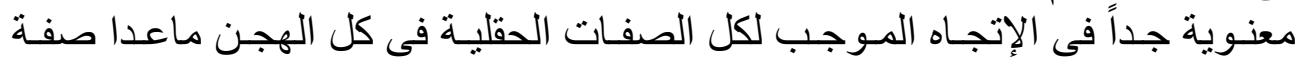

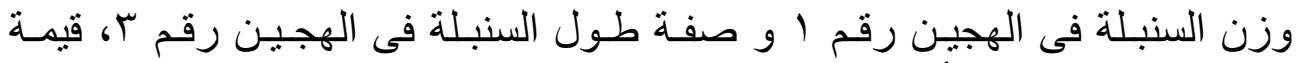

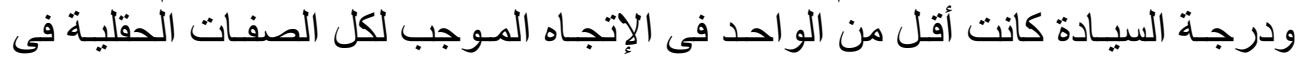

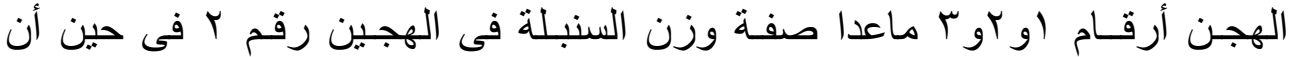

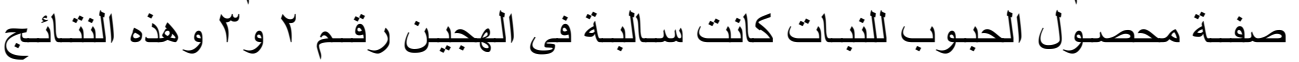

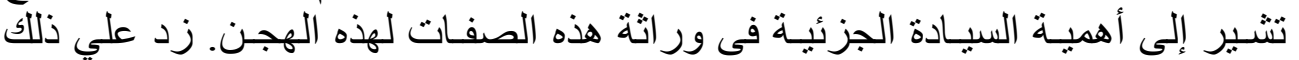

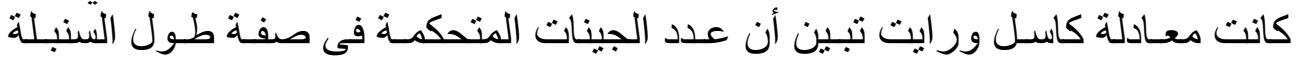

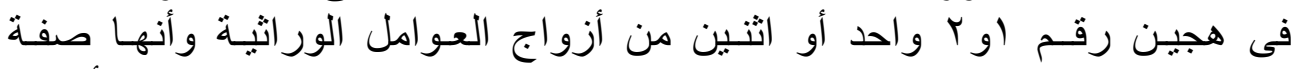

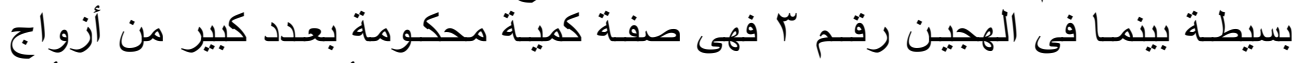

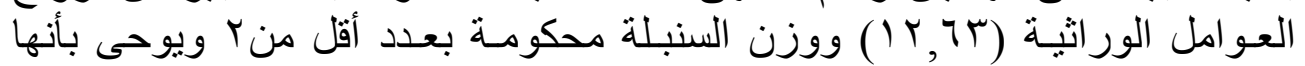




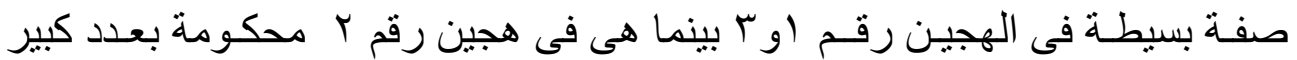

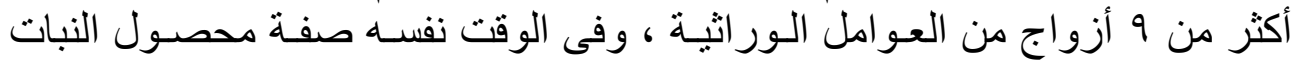

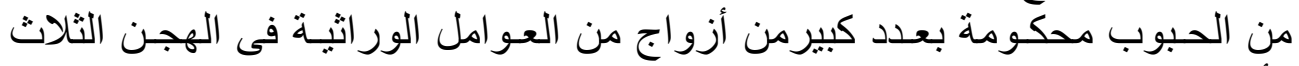

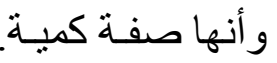

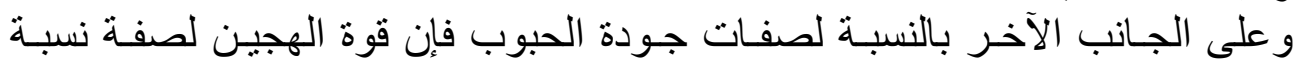

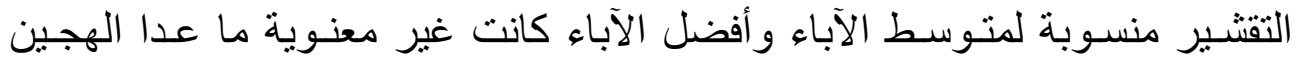

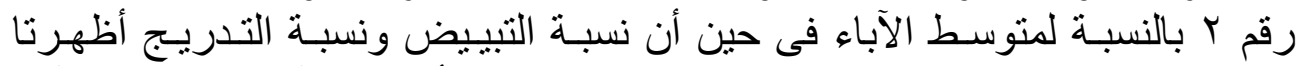

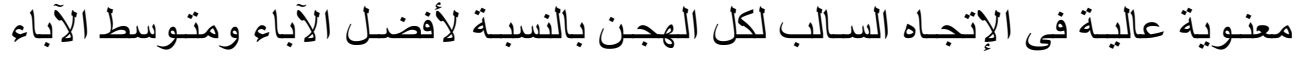

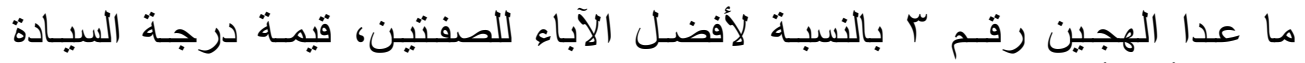

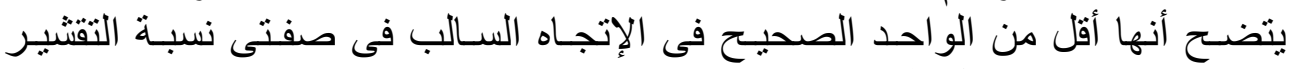

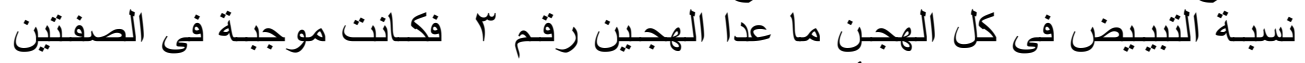

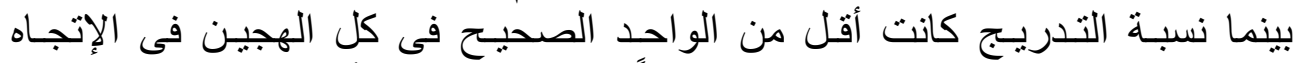

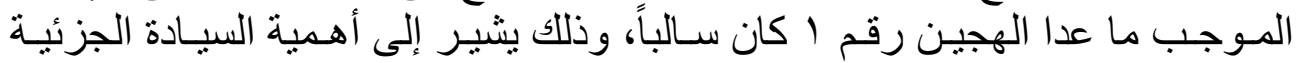

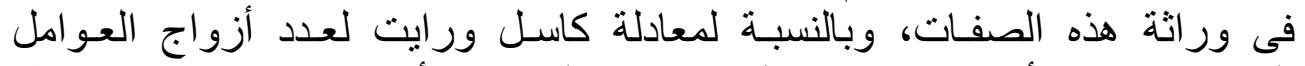

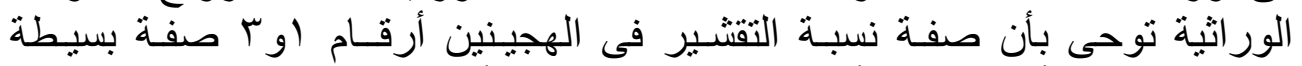

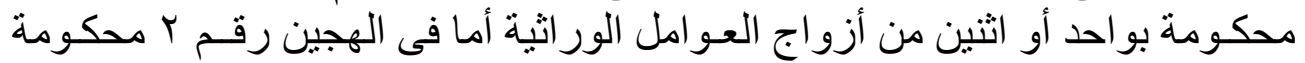

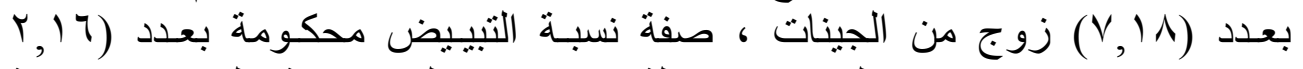

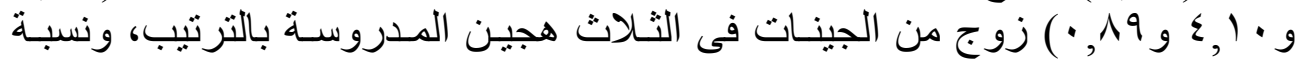

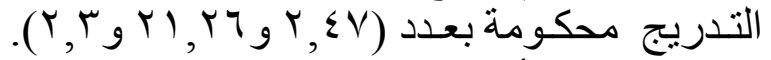

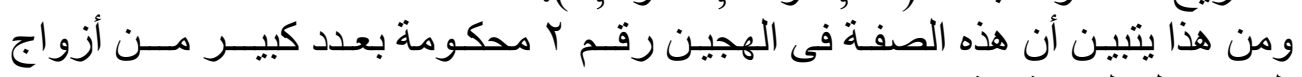

